\title{
Evaluation in vivo of biocompatibility of differents resin- modified cements for bonding orthodontic bands
}

\author{
JANAINA A. MESQUITA ${ }^{1}$, ROGÉRIO LACERDA-SANTOS ${ }^{2}$, GÊISA A.M. SAMPAIO ${ }^{1}$, \\ GUSTAVO P. GODOY ${ }^{3}$, CASSIANO F.W. NONAKA ${ }^{4}$ and POLLIANNA M. ALVES ${ }^{4}$

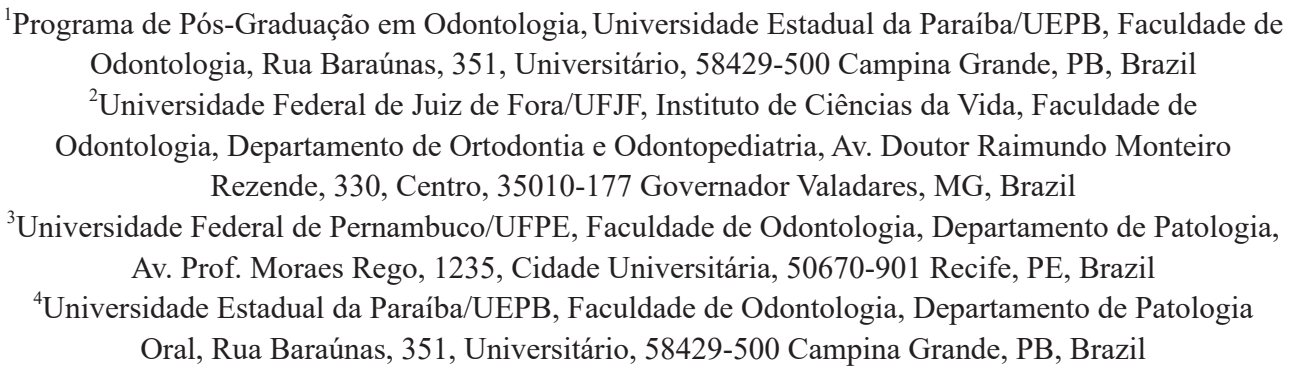

Manuscript received on May 8, 2017; accepted for publication June 23, 2017

\begin{abstract}
The focus of this study was to test the hypothesis that there would be no difference between the biocompatibility of resin-modified glass ionomer cements. Sixty male Wistar rats were selected and divided into four groups: Control Group; Crosslink Group; RMO Group and Transbond Group. The materials were inserted into rat subcutaneous tissue. After time intervals of 7, 15 and 30 days morphological analyses were performed. The histological parameters assessed were: inflammatory infiltrate intensity; reaction of multinucleated giant cells; edema; necrosis; granulation reaction; young fibroblasts and collagenization. The results obtained were statistically analyzed by the Kruskal-Wallis and Dunn test $(P<0.05)$. After 7 days, Groups RMO and Transbond showed intense inflammatory infiltrate $(P=0.004)$, only Group RMO presented greater expression of multinucleated giant cell reaction $(P=0.003)$ compared with the control group. After the time intervals of 15 and 30 days, there was evidence of light/moderate inflammatory infiltrate, lower level of multinucleated giant cell reaction and thicker areas of young fibroblasts in all the groups. The hypothesis was rejected. The Crosslink cement provided good tissue response, since it demonstrated a lower level of inflammatory infiltrate and higher degree of collagenization, while RMO demonstrated the lowest level of biocompatibility.
\end{abstract}

Key words: Dental materials, orthodontic cements, biocompatibility test, inflammation, multinucleated giant cells.

Correspondence to: Rogério Lacerda-Santos

E-mail: lacerdaorto@hotmail.com 


\section{INTRODUCTION}

The resin modified glass ionomer cement (RMGIC), the hybrid version of conventional glass ionomer cement (GIC), is composed of glass particles, acids, initiators, additives and a resinous system of organic monomers (Corekci et al. 2013). This material has been increasingly used by orthodontists for cementing orthodontic bands, due to the favorable physical and chemical properties capable of providing good retentiveness, fluoride release capacity and being practical to use (Malkoc et al. 2010). However, there are indications that this cement may present cytotoxicity, genotoxicity and inadequate biocompatibility (Angelieri et al. 2011, Selimović-Dragaš et al. 2012).

Studies in vitro have demonstrated that the RMGICs are capable of inducing cytotoxic effects on oral tissues, due to the presence of substances released during polymerization, such as hydrophilic monomers (Angelieri et al. 2011, Corekci et al. 2013, Selimović-Dragaš et al. 2012, Xie et al. 2008). Nevertheless, although these studies have evaluated the biologic properties of RMGICs, in vivo models are required to provide a more critical analysis with regard to the biocompatibility of these resin cements (Zhou et al. 2011).

Biocompatibility is evaluated by means of analyzing the different cell reactions after the materials have been in contact with the vascularized tissues (Santos et al. 2010). This is one of the most important properties to be evaluated, because these biomaterials may trigger inflammatory reactions in adjacent tissues by direct interaction with the tissues or the solubility of the components in the oral cavity (Malkoc et al. 2010, Santos et al. 2014a, Selimović-Dragaš et al. 2012).

In biocompatibility tests, tissue reactions are most frequently studied by means of morphological analyses, in which the most intense inflammatory reactions or inadequate tissue repair processes may be observed in the presence of irritant or less compatible materials (Boaventura et al. 2012, Yang et al. 2012). However, in spite of the importance of analyzing the biologic effect of RMGICs, little is known about the level of compatibility of these materials with tissues.

In this context, the focus of this doubleblind randomized study was to test the hypothesis that there would be no difference between the biocompatibility of resin-modified glass ionomer cements by an in vivo test and morphological analysis of the tissue inflammatory response after being in contact with these materials.

\section{MATERIALS AND METHODS}

\section{STUDY DESIGN}

The study sample consisted of 60 adult male Wistar rats, weighing between 200 and $300 \mathrm{~g}$, which were divided into four groups according to the materials tested: Control Group (Control, Polyethylene tube), Transbond Group (Transbond Plus Light Cure Band ${ }^{\circledR}$ ); RMO Group (RMO Band Cement ${ }^{\circledR}$ ) and Crosslink Group (Crosslink Orthodontic Band Cement $\left.{ }^{\circledR}\right)$ (Table I). This in vivo laboratory study was previously approved by the Ethics Committee on Research Involving Animal Experimentation, Protocol/CSTR, No.0102016.

\section{PREPARATION OF SAMPLES AND MATERIALS}

The rats were anesthetized with an intraperitoneal injection of sodium thiopental $(50 \mathrm{mg} / \mathrm{kg})$ (Cristália, Campinas, SP, Brazil). After this, trichotomy was performed in the dorsal region of each animal, using razor blades $(4 \times 4 \mathrm{~cm})$ and antisepsis of the operative field with $4 \%$ chlorhexidine digluconate. On the midline, equidistant from the point of insertion of the animal's tail and head, an incision approximately $8 \mathrm{~mm}$ long was made and the subcutaneous tissue was divulsed laterally, promoting tunneling in the lateral direction for the purpose of inserting implants of the materials. Each rat received one polyethelyne tube implant 
TABLE I

Composition of Transbond ${ }^{\circledR}$, Crosslink ${ }^{\circledR}$ and $R M O \circledR$ cements evaluated in this study.

\begin{tabular}{|c|c|c|c|c|}
\hline Group & Cements & Composition & Manufacturer & Lot No. \\
\hline $\mathrm{C}$ & Control & Polyethylene tube & ------- & ------- \\
\hline CK & $\begin{array}{l}\text { Crosslink } \\
\text { Orthodontic } \\
\text { Band Cement }\end{array}$ & $\begin{array}{l}\text { Monomers, Fluroaluminosilicate glass, } \\
\text { Cure promoters and pigments }\end{array}$ & TP Orthodontics, La Porte, IN, USA & 32012000 \\
\hline RMO & $\begin{array}{l}\text { RMO Band } \\
\text { Cement }\end{array}$ & $\begin{array}{l}\text { Aromatic and Aliphatic Dimethacrylate } \\
\text { Monomers and Fluroaluminosilicate glass }\end{array}$ & RMO, Denver, CO, USA & A041813 \\
\hline $\mathrm{TP}$ & $\begin{array}{l}\text { Tansbond } \\
\text { Plus Light } \\
\text { Cure Band }\end{array}$ & $\begin{array}{l}2 \text { hydroxy, 1,3-dimethacryloxypropane, } \\
\text { cure promoters, fluoroaluminosilicate glass, } \\
\text { silane and blue pigment }\end{array}$ & 3MUnitek, Monrovia, CA,USA & N4 05305 \\
\hline
\end{tabular}

(0.8 $\mathrm{mm}$ long and $0.5 \mathrm{~cm}$ internal diameter), which was previously kept in $70 \%$ alcohol for $120 \mathrm{~min}$, washed with deionized water and finally autoclaved at a temperature of $110^{\circ} \mathrm{C}$ for $20 \mathrm{~min}$ and used as inoculation vehicles for the materials tested.

The RMGICs were manipulated in accordance with the manufacturers' instructions, and then introduced into the openings at the extremities of the polyethylene tubes by using a spreader. Afterwards the RMGICs were polymerized with a LED appliance (Radii, SDI, Baywater, VIC, Australia) according to the light polymerization time of 40 seconds. The light intensity of the light polymerizing appliance $\left(1000 \mathrm{mw} / \mathrm{cm}^{2}\right)$ was checked with a radiometer (Model 100, Demetron Research Corporation, Danbury, CT, USA) immediately before each polymerization procedure. After the RMGICs were polymerized, the tubes were implanted in the subcutaneous tissue of the rats. In the control group, an empty polyethylene tube was used, which simulated the trauma induced and possible contamination of the tubes.

After the materials were implanted, the surgical recesses were sutured and on conclusion of the procedure, the animals received an intramuscular injection of $0.2 \mathrm{ml}$ of veterinary pentabiotic (Wyeth Laboratory, New York, NY, USA), and an injection of sodium dipyrone $(0.3 \mathrm{ml} / 100 \mathrm{~g}$, Novalgina, SP, Brazil). All the procedures were performed in compliance with the guidelines of the Canadian Council on Animal Care (1981). The animals of each group were kept in individual cages at a temperature ranging from $22^{\circ} \mathrm{C}$ to $26^{\circ} \mathrm{C}$ under a 12 hour light-dark cycle, under adequate conditions with appropriate rations and water ad libitum.

After time intervals of 7, 15 and 30 days, the animals were anesthetized to obtain excisional biopsies of the implant area, including sufficient normal surrounding tissue. Each group consisted of 5 rats per each time interval, totaling 15 samples per group. Afterwards the rats were sacrificed by cervical dislocation technique after having been sedated with sodium thiopental $(50 \mathrm{mg} / \mathrm{kg})$.

\section{HISTOLOGICAL ANALYSIS}

The specimens were prepared on glass slides by Hematoxylin and Eosin (HE) staining, and afterwards evaluated under an optical microscope, Leica DM500® (Leica Microsystems, Germany), at $100 x, 400 x$ and $1000 x$ magnifications. According to the methodology proposed by studies (Garcia et al. 2010, Santos et al. 2010), the histological parameters assessed were: Inflammatory infiltrate intensity; edema; necrosis; multinucleated giant cell reaction, granulation reaction; young fibroblasts and collagenization, with the following scores being considered: $0-$ scarce; 1- light (when scarcely present, or in very 
small groups); 2 - moderate (when densely present, or in some groups); 3 - intense (when found in the entire field, or present in large numbers, indicating a high degree of severity), for all the histopathological parameters. These values represent the mean of scores of the sum of five representative histological sections of the tissue evaluated ( $\mathrm{n}=5$, per group). The histological sections were randomly assessed at 5 different points of the tissue, adjacent to the specimen. For the edema parameter, a macroscopic qualitative visual analysis of the biopsy area was also considered, analyzing the presence or macroscopic absence of edema immediately before the biopsies were obtained. The histopathological evaluation was made by a single, previously calibrated evaluator $(\mathrm{Kappa}=0.85)$ who was blind to the evaluation of groups.

\section{STATISTICAL ANALYSIS}

The data were tabulated and analyzed in the statistical software program BioEstat version 5.0 (Mamirauá, Manaus, AM, Brazil). The statistical method was chosen based on the model of distribution and variance of data evaluated by the KolmogorovSmirnov and Levene tests, respectively. Thus, the results of the cellular events were submitted to the Kruskal-Wallis test, and afterwards the Dunn test to determine the differences between the groups $(P<0.05)$.

\section{RESULTS}

In the time interval of 7 days, the presence of chronic inflammatory infiltrate was observed in all the groups, however, it was shown to be more intense in the RMO and Transbond groups $(P=0.004)$. Granulation reaction shown to be more intense in all the groups analyzed in comparison with the control group $(P=0.002)$ and the multinucleated giant cell reaction was more evident only for Group RMO in this time interval $(P=0.003)$. As regards the histopathological parameters - edema and necrosis-although edema was observed in all the groups, and necrosis in Groups Crosslink and Transbond after 7 days, no significant differences were observed (Table II) (Figures 1a-1d). In the macroscopic visual evaluation, the presence of edema was observed for the Crosslink, RMO and Transbond groups, but with distinct macroscopic perception only when compared with the control group, in time interval of 7 days.

In the time interval of 15 days, there was evidence of moderate inflammatory infiltrate, lower quantity of multinucleated giant cells, areas of young fibroblasts and light collagenization level in all the groups (Figures 1e-1h). In the time interval of 30 days, light inflammatory infiltrate and a thick layer of collagen fibers could be visualized as tissue reaction against the cements (Figures 1i-11). Relative to the parameter collagenization, only Group RMO presented low degree of collagenization after 15 $(P=0.008)$ and 30 days $(P=0.014)$ in comparison with the control group (Table II).

Over the course of the time evaluated, the authors observed that the inflammatory infiltrate intensity, granulation reaction, and multinucleated giant cell reaction parameters diminished progressively, while the presence of young fibroblasts and areas of collagenization increased for all the groups evaluated.

\section{DISCUSSION}

Various studies have sought to evaluate the biologic properties of materials used in dentistry (Cunha et al. 2011, Lacerda-Santos et al. 2016a, b, Santos et al. 2010, Yang et al. 2012), however, there is still a scarcity of researches in the literature, involving orthodontic cements. In view of this, the authors opted to analyze the biocompatibility of three types of RMGICs frequently used by orthodontists for band cementation: Transbond ${ }^{\circledR}, \mathrm{RMO}^{\circledR}$ and Crosslink ${ }^{\circledR}$. 
TABLE II

Mean of scores attributed to groups, after time intervals of 7, 15 and 30 days, for the 7 histological parameters evaluated.

\begin{tabular}{|c|c|c|c|c|c|c|}
\hline \multirow[t]{2}{*}{ Condition } & \multirow[t]{2}{*}{ Time } & \multicolumn{4}{|c|}{ Groups } & \multirow[t]{2}{*}{ P-value } \\
\hline & & Crosslink & RMO & Transbond & Control & \\
\hline \multirow[t]{3}{*}{ Inflammatory Infiltrate } & 7 days & $1.6^{\mathrm{AB}}$ & $2.4^{\mathrm{A}}$ & $2.2^{\mathrm{A}}$ & $1.0^{\mathrm{B}}$ & 0.004 \\
\hline & 15 days & 1.2 & 1.0 & 1.4 & 0.6 & 0.084 \\
\hline & 30 days & 0.6 & 0.6 & 0.8 & 0.4 & 0.663 \\
\hline \multirow[t]{3}{*}{ Edema } & 7 days & 1.2 & 0.8 & 1.0 & 0.4 & 0.059 \\
\hline & 15 days & 0.4 & 0.0 & 0.0 & 0.0 & 0.096 \\
\hline & 30 days & 0.0 & 0.0 & 0.0 & 0.0 & 1.000 \\
\hline \multirow[t]{3}{*}{ Necrosis } & 7 days & 0.4 & 0.0 & 0.2 & 0.0 & 0.251 \\
\hline & 15 days & 0.0 & 0.0 & 0.0 & 0.0 & 1.000 \\
\hline & 30 days & 0.0 & 0.0 & 0.0 & 0.0 & 1.000 \\
\hline \multirow[t]{3}{*}{ Granulation Tissue } & 7 days & $2.0^{\mathrm{A}}$ & $2.0^{\mathrm{A}}$ & $2.0^{\mathrm{A}}$ & $1.2^{\mathrm{B}}$ & 0.002 \\
\hline & 15 days & 0.8 & 0.6 & 1.2 & 0.4 & 0.132 \\
\hline & 30 days & 0.4 & 0.2 & 0.2 & 0.2 & 0.859 \\
\hline \multirow[t]{3}{*}{ Giant Cells } & 7 days & $1.0^{\mathrm{AB}}$ & $1.6^{\mathrm{A}}$ & $1.0^{\mathrm{AB}}$ & $0.2^{\mathrm{B}}$ & 0.003 \\
\hline & 15 days & 0.4 & 0.6 & 0.8 & 0.2 & 0.283 \\
\hline & 30 days & 0.2 & 0.4 & 0.8 & 0.2 & 0.191 \\
\hline \multirow[t]{3}{*}{ Young Fibroblasts } & 7 days & 1.0 & 1.4 & 1.2 & 1.8 & 0.062 \\
\hline & 15 days & 1.8 & 1.8 & 1.8 & 2.6 & 0.055 \\
\hline & 30 days & 1.8 & 1.8 & 1.8 & 2.4 & 0.169 \\
\hline \multirow[t]{3}{*}{ Collagenization } & 7 days & 0.0 & 0.2 & 0.0 & 0.4 & 0.251 \\
\hline & 15 days & $1.2^{\mathrm{AB}}$ & $1.0^{\mathrm{A}}$ & $1.6^{\mathrm{AB}}$ & $2.2^{\mathrm{B}}$ & 0.008 \\
\hline & 30 days & $2.0^{\mathrm{AB}}$ & $1.8^{\mathrm{A}}$ & $2.2^{\mathrm{AB}}$ & $2.8^{\mathrm{B}}$ & 0.014 \\
\hline
\end{tabular}

These values represent the mean of scores of the sum of five representative histological sections of the tissue evaluated ( $\mathrm{n}=5$, per group). Means followed by different letters express statistically significant difference $(P<05)$ based on non-parametric KruskalWallis Test, followed by the Dunn multiple comparisons test.

In this study, the method used for evaluating the biocompatibility of the composites in rat subcutaneous tissue was conducted in accordance with the specifications of ISSO Standards- 6876 and 10993-5 that propose the implantation of biomaterials in the tissues of laboratory animals (Aminozarbian et al. 2012). Although this methodology does not faithfully reproduce the conditions in the oral cavity, it provides important preliminary information about the biologic properties of dental materials and characteristics of tissue reactions (Aminozarbian et al. 2012, Boaventura et al. 2012, Saghiri et al. 2012, Yang et al. 2012, Viola et al. 2012). The histological parameters were evaluated after time intervals of 7 ,
15 and 30 days, as observed in other studies (Cunha et al. 2011, Lacerda-Santos et al. 2014, Santos et al. 2014b, Vosoughhosseini et al. 2012).

When the different histopathological characteristics in rat subcutaneous tissue are observed at various time intervals after being in contact with the materials tested, they allow a more precise evaluation, because of the dynamism of inflammatory reactions (Zhou et al. 2011). In this study, the first analysis was performed after 7 days because, it is only after this period that a more organized inflammatory reaction can be expected (Santos et al. 2010, 2014a). Whereas, the analyses after 30 days are for the purpose of verifying the reparative capacity of the tissue after the aggressive 

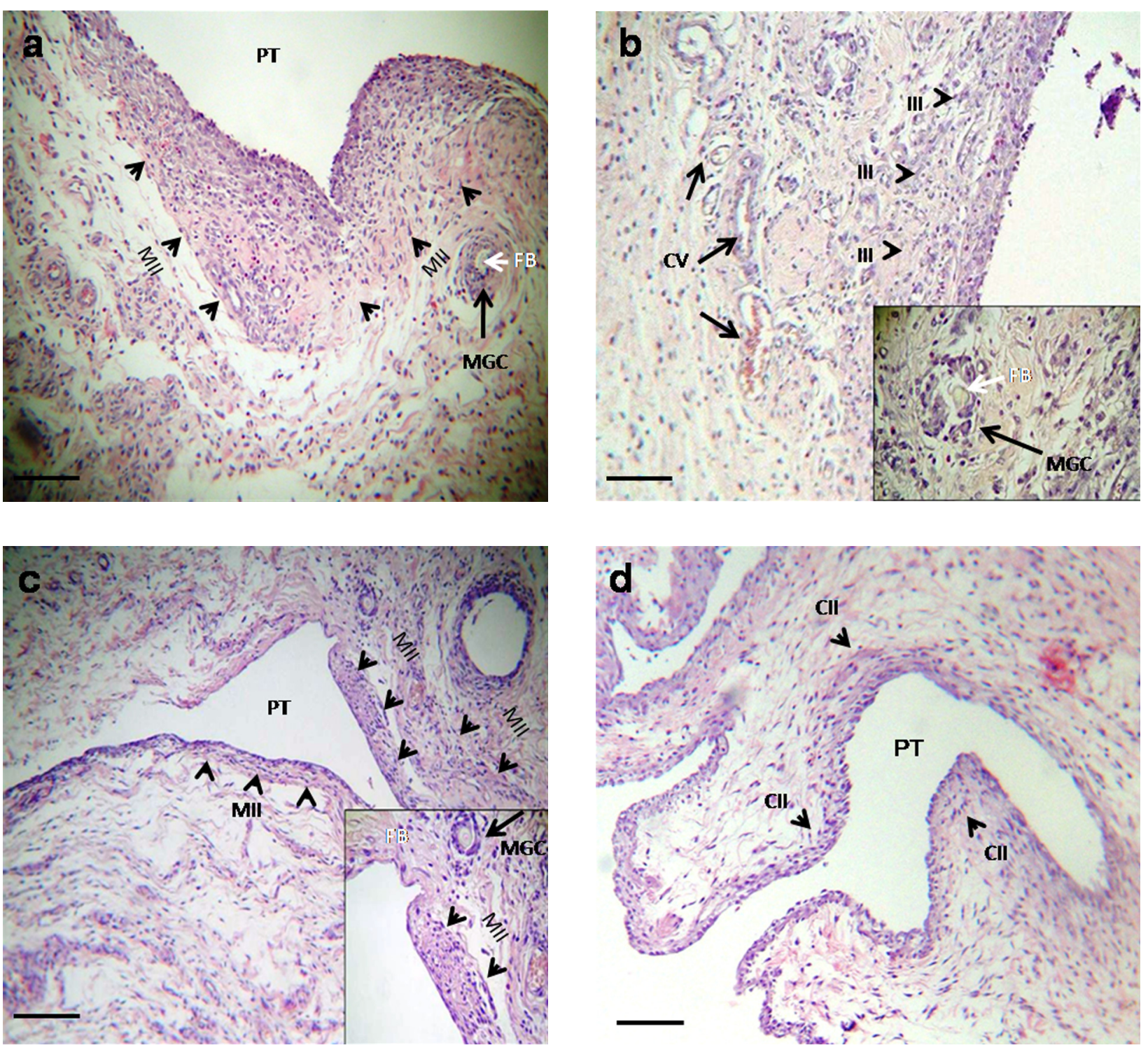

1a) Group Crosslink: presence of moderate chronic inflammatory infiltrate (MII) surrounding the cavity, presence of multinucleated giant cells (MGC) near the foreign body material (FB) (HE, 100X magnification; scale: $100 \mu \mathrm{m})$. Area of polyethylene tube implant (PT).

1b) Group RMO: evidence of intense inflammatory infiltrate (III), predominantly mononuclear, and granulation reaction with congested vessels (CV) (HE, 100X magnification; scale: $100 \mu \mathrm{m})$. At greater magnification, one observes the reaction of multinucleated giant cells (MGC) near the foreign body material (FB) (HE, 400X magnification; scale: $25 \mu \mathrm{m}$ ). Area of polyethylene tube implant (PT).

1c) Group Transbond: evidence of moderate inflammatory infiltrate (MII) (HE, 100X magnification; scale: $100 \mu \mathrm{m})$, and the presence of multinucleated giant cells (MGC) near the foreign body material (FB) (HE, 400X magnification; scale: $25 \mu \mathrm{m}$ ). Area of polyethylene tube implant (PT).

1d) Group Control: evidence of slight chronic inflammatory infiltrate (CII) and scarce granulation reaction at the limits of the cavity (HE, 100X magnification; scale: $100 \mu \mathrm{m}$ ). Area of polyethylene tube implant (PT). 

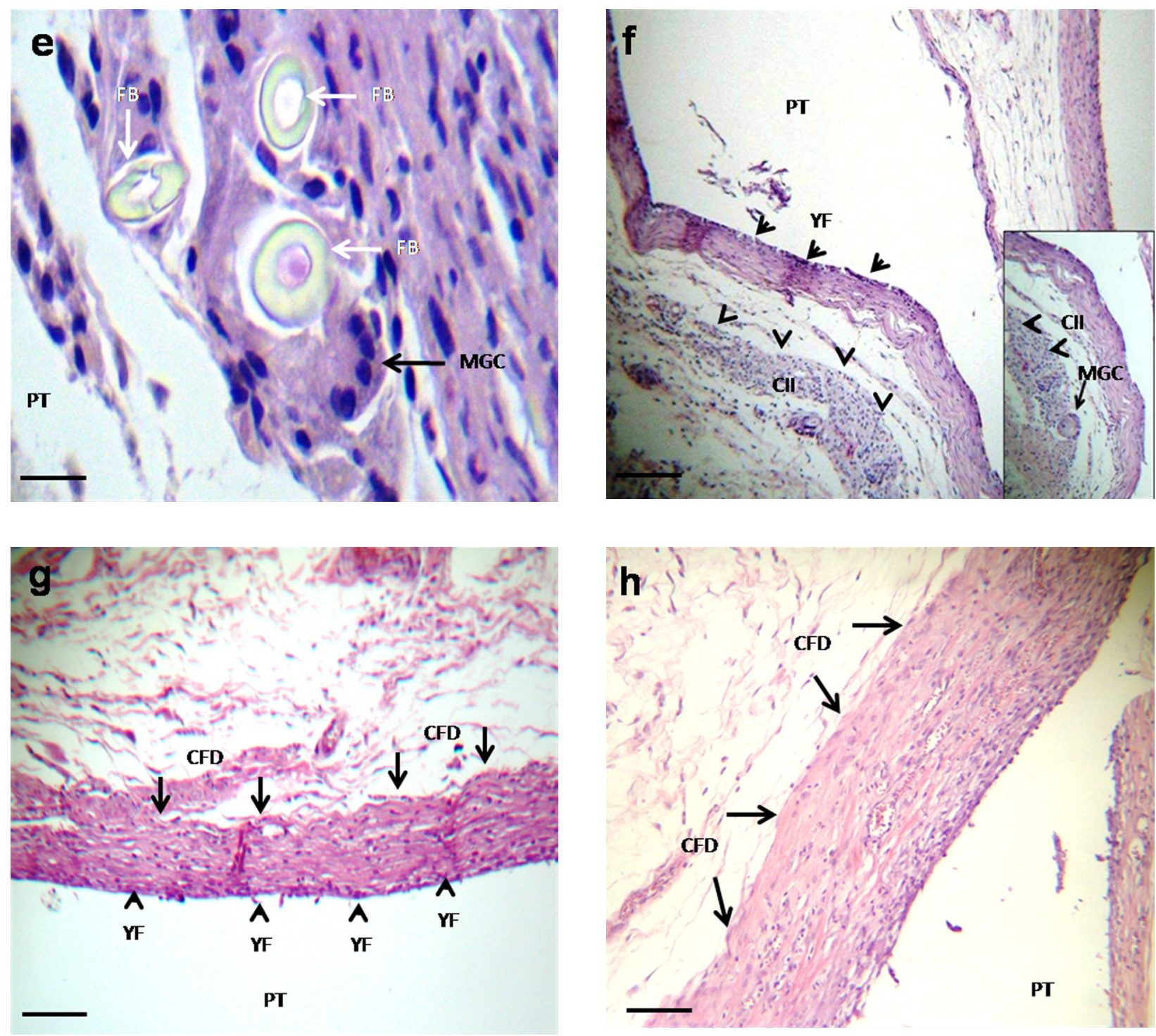

1e) Group Crosslink: presence of multinucleated giant cells (MGC) reaction involving remnants of the cement, as foreign body material (FB) (HE, 400X magnification; scale: $25 \mu \mathrm{m}$ ). Area of polyethylene tube implant (PT).

1f) Group RMO: Presence of chronic inflammatory infiltrate (CII) near the cavity, as well as the presence of young fibroblasts (YF) (HE, 100X magnification; scale: $100 \mu \mathrm{m}$ ). At greater magnification, presence of multinucleated giant cells (MGC) (HE, 400X magnification; scale: $25 \mu \mathrm{m}$ ). Area of polyethylene tube implant (PT).

1g) Group Transbond: Collagen fibers deposition (CFD) arranged in parallel bundles surrounding the cavity, and presence of young fibroblasts (YF) (HE, 100X magnification; scale: $100 \mu \mathrm{m})$. Area of polyethylene tube implant (PT).

1h) Group Control: evidence thick layer of collagen fibers deposition (CFD) and collagenization (HE, 100X magnification; scale: $100 \mu \mathrm{m})$. Area of polyethylene tube implant (PT). 

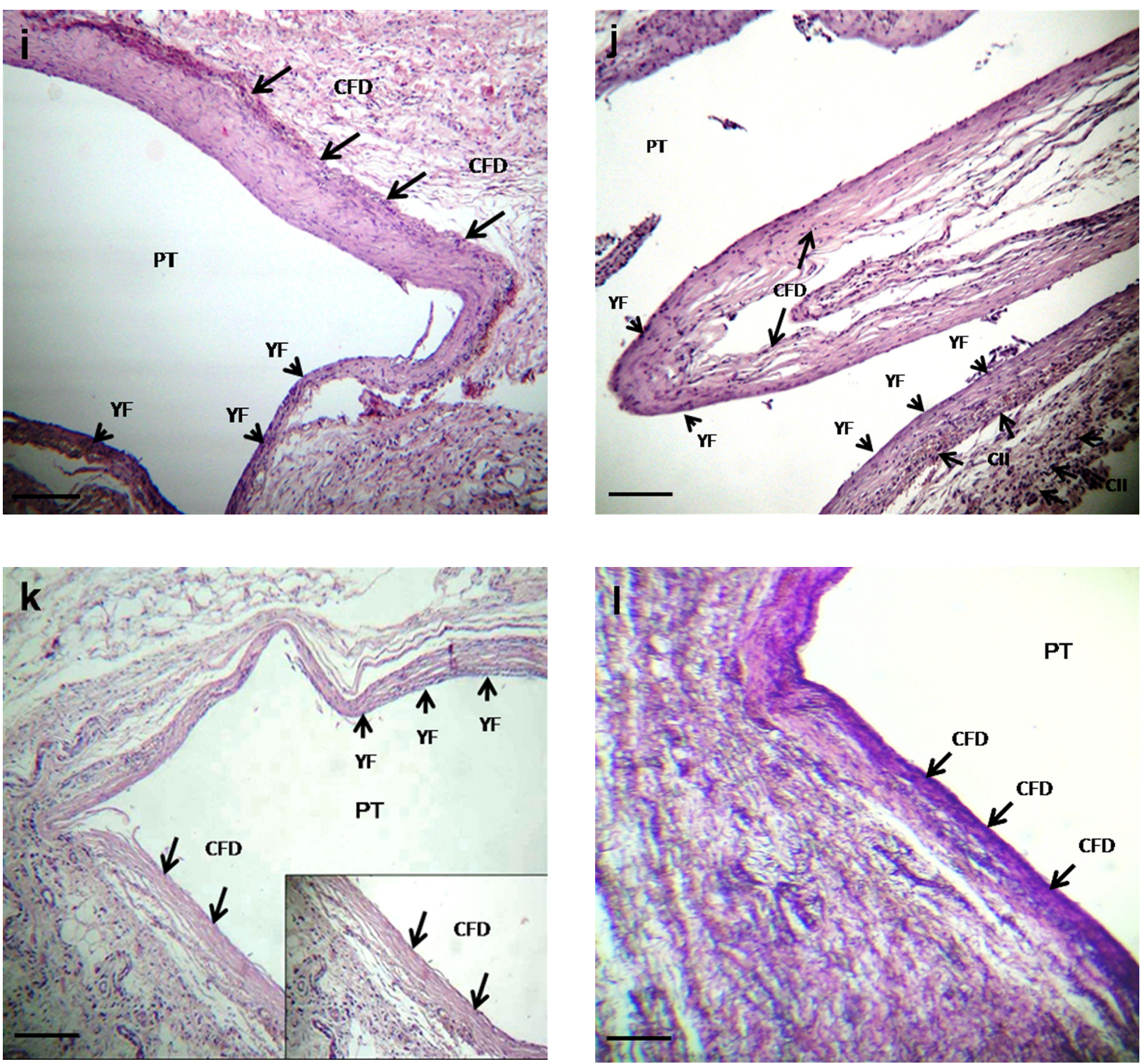

1i) Group Crosslink: presence of thick area of collagenization enveloping the cavity with collagen fibers deposition (CFD) and young fibroblasts (YF) (HE, 100X magnification; scale: $100 \mu \mathrm{m}$ ). Area of polyethylene tube implant (PT).

1j) Group RMO: evidence a moderate collagenization with collagen fibers deposition (CFD) and young fibroblasts (YF), as well as the presence of a chronic inflammatory infiltrate (CII) in the inferior area of cavity (HE, 100X magnification; scale: $100 \mu \mathrm{m}$ ). Area of polyethylene tube implant (PT).

1k) Group Transbond: cavity totally enveloped by a thick layer of collagen fibers deposition (CFD) and young fibroblasts (YF) (HE, 100X magnification; scale: $100 \mu \mathrm{m}$ ). At greater magnification, observed collagen fibers deposition (CFD) (HE, 400X magnification; scale: $25 \mu \mathrm{m}$ ) are evident. Area of polyethylene tube implant (PT).

11) Group Control: collagenization intense with collagen fibers deposition (CFD) involving the cavity (HE, 400X magnification; scale: $25 \mu \mathrm{m})$. Area of polyethylene tube implant (PT). 
challenge initially caused by the materials tested (Costa et al. 2011).

After the period of 7 days, the $\mathrm{RMO}^{\circledR}$ and Transbond $^{\circledR}$ demonstrated intense inflammatory infiltrate when compared with the control group $(P=0.004)$. This initial inflammatory response reflected the attempt by the tissue to induce the process of degradation of the materials through the inflammatory cells recruited to the surrounding tissue and in the direction towards the surface of the cements (Ghanaati et al. 2010, Malkoc et al. 2010). In addition, it suggested that the elution of toxic substances released by these cements was capable of stimulating the production of reactive oxygen species (ROS), and increasing the expression of COX-2/PGE 2, which are potent chemical mediators, capable of potentiating the inflammatory response (Costa et al. 2011).

As regards the presence of multinucleated giant cells after 7 days, $\mathrm{RMO}^{\circledR}$ cement presented intense macrophagic reaction in the attempt to limit/ remove the residues liberated by this cement and considered non inert to the body $(P=0.003)$. This suggested that this material might have released more irritant substances in the initial periods than the other cements (Saghiri et al. 2012). The presence of rests of cement close to the cavity observed in some samples in subsequent periods, demonstrated that these biomaterials were not easily digested by the macrophages or removed by local lymphatic drainage (Souza et al. 2006).

Furthermore, all the groups demonstrated intense granulation reaction with the presence of a larger number of blood vessels, which clinically suggested the presence of hyperemic areas $(P=0.002)$. The granulation reaction induced by the cements was predictable in the initial period, since it functioned as a pathway for the macrophages to reach the implant site (Ghanaati et al. 2010).

After 15 and 30 days, progressive reduction in the inflammatory response; increase in the production of young fibroblasts; and deposition of collagen fibers were observed in all the groups. This occurred due to the tissue remodeling process that frequently occurs after 15 days (Shapiro et al. 2011). In this study, $\mathrm{RMO}^{\circledR}$ cement exhibited a larger quantity of collagenization compared with the control group after the time interval of 15 days $(P=0.008)$ and 30 days $(P=0.014)$. The authors suggest that substances released by this cement had induced intense inflammatory response in the initial periods and because of this, the tissue had not been able to achieve adequate remodeling even after 30 days of follow-up.

The $\mathrm{RMO}^{\circledR}$ contains BisGMA, a monomer with a low degree of conversion values due to the presence of strong hydrogen bond and $\pi-\pi$ interactions provided by bisphenol-A (Gajewski et al. 2012). Normally, the monomers present in these materials are converted into polymers during the polymerization process, however, inadequate conversion would result in a larger quantity of residual monomers capable of causing a significant cytotoxic effect and affecting the compatibility of the material with the oral tissues (Lacerda-Santos et al. 2014, 2016a, Santos et al. 2012). LacerdaSantos et al. (2014) evaluated the relationship between biocompatibility and degree of conversion of RMGICs and demonstrated that the cement that had the lowest degree of conversion was related to a more intense inflammatory response after 7 days, and lower quantity of collagenization after 30 days in comparison with cements that presented higher degrees of conversion.

Whereas the TransbondPlus ${ }^{\circledR}$ cement, composed of 2- hydroxyl-1, 3- Dimethacryloxypropane, has a good degree of conversion, which may justify the fact that this material obtained a better response when compared with the $\mathrm{RMO}^{\circledR}$ group over the course of time (Corekci et al. 2013, Malkoc et al. 2010). Malkoc et al. (2010) when evaluating the cytotoxicity of three RMGICs, demonstrated that although all the materials presented significant cytotoxicity in comparison with the control group, 
the cement that contained BisGMA presented the worst results when compared with Transbond Plus ${ }^{\circledR}$.

With regard to Crosslink ${ }^{\circledR}$ cement, the authors suggest that the monomers of which it is composed have a good degree of conversion capable of providing greater chemical stability, and consequently, less aggression to the tissue; similar to that observed with Transbond Plus ${ }^{\circledR}$ cement because, based on the histopathological parameters evaluated, Crosslink ${ }^{\circledR}$ presented good biologic compatibility. At present, with the improvement in the manufacturing process of RMGICs, a lower quantity of residual monomers has been found, however, there is still sufficient presence of free monomers to contribute to the cytotoxic effects and interfere in the biocompatibility of these cements (Selimović-Dragaš et al. 2012).

Among the possible effects of the presence of residual monomers of RMGICs on the oral cavity during orthodontic treatment, the authors have observed foreign body gingivitis, increased risk of gingival bleeding, prolonged inflammatory process and chronic gingival infection. Careful removal of the excesses of these cements at the time of cementing bands may be an effective preventive measure to reduce these effects. Studies in vivo may also help to elucidate the biologic compatibility of RMGICs, considering that orthodontic bands are continually in contact with the gingival tissue for long periods of time.

\section{CONCLUSIONS}

The hypothesis was rejected. The Crosslink ${ }^{\circledR}$ cement provided the best tissue response, with less inflammatory infiltrate and a higher degree of collagenization being observed, followed by Transbond Plus ${ }^{\circledR}$ due to its tissue repair capacity. The $\mathrm{RMO}^{\circledR}$ cement demonstrated the lowest level of biocompatibility, due to the intense inflammatory infiltrate in the initial periods, and lower degree of collagenization after 15 and 30 days. This suggested that the $\mathrm{RMO}^{\circledR}$ could generate a more lasting inflammatory process in gingival tissues and therefore be clinically harmful.

\section{REFERENCES}

AMINOZARBIAN MG, BARATI M, SALEHI I AND MOUSAVI SB. 2012. Biocompatibility of mineral trioxide aggregate and three new endodontic cements: An animal study. J Dent Res 9: 54-59.

ANGELIERI F, CARLIN V, MARTINS RA AND RIBEIRO DA. 2011. Biomonitoring of mutagenicity and cytotoxicity in patients undergoing fixed orthodontic therapy. Am J Orthod Dentofacial Orthop 139: e399-404.

BOAVENTURA JMC, BERTOLINI MJ, PADOVANI GC, DE OLIVEIRA MR, ZAGHETE MA, DE OLIVEIRA JÚNIOR OB AND DE ANDRADE MF. 2012. Tissue response to experimental dental cements prepared from a modified power glass composition. Dent Mater 31: 583592.

COREKCI B, TOY E, MALKOC S, OZTURK B AND GUNDUZ B. 2013. Effects of time delay on degree of conversion of contemporary orthodontic band adhesives. Turk Ortod Derg 26: 23-29.

COSTA CA, RIBEIRO AP, GIRO EM, RANDALL RC AND HEBLING J. 2011. Pulp response after application of two resin modified glass ionomer cements (RMGICs) in deep cavities of prepared human teeth. Dent Mater 27: e158170.

CUNHA SA, RACHED FJ, ALFREDO E, LEÓN JE AND PEREZ DE. 2011. Biocompatibility of sealers used in apical surgery: a histological study in rat subcutaneous tissue. Braz Dent J 22: 299-305.

GAJEWSKI VES, PFEIFER CS, FRÓES-SALGADO NRG, BOARO LC AND BRAGA RR. 2012. Monomers used in resin composites: degree of conversion, mechanical properties and water sorption/solubility. Braz Dent J 23: 508-514.

GARCIA LFR, SOUZA FCP, TEÓFILO JM, CESTARI A, CALEFI PS, CIUFFI KJ AND NASSAR EJ. 2010. Synthesis and biocompatibility of an experimental glass ionomer cement prepared by a non-hydrolytic sol-gel method. Braz Dent J 21: 499-507.

GHANAATIS, WILLERSHAUSEN I, BARBECK M, UNGER RE, JOERGENS M, SADER RA, KIRKPATRICK CJ AND WILLERSHAUSEN B. 2010. Tissue reaction to sealing materials: different view at biocompatibility. Eur J Med Res 15: 483-492.

LACERDA-SANTOS R, DE FARIAS MI, DE CARVALHO FG, PITHON MM, ALVES PM, TANAKA OM AND GUÊNES GM. 2014. In vivo biocompatibility versus 
degree of conversion of resin-reinforced cements in different time periods. Microsc Res Tech 77: 335-340.

LACERDA-SANTOS R, DE MENESES IHC, SAMPAIO GAM, PITHON MM AND ALVES PM. 2016a. Effect of degree of conversion on in vivo biocompatibility of flowable resin used for bioprotection of mini-implants. Angle Orthod 86: 157-163.

LACERDA-SANTOS R, SAMPAIO GAM, MOURA MFL, CARVALHO FG, DOS SANTOS A, PITHON MM AND ALVES PM. 2016b. Effect of different concentrations of chlorhexidine in glass-ionomer cements on in vivo biocompatibility. J Adhes Dent 18: 325-330.

MALKOC S, COREKCI B, BOTSALI HE, YALÇIN M AND SENGUN A. 2010. Cytotoxic effects of resinmodified orthodontic band adhesives. Are they safe? Angle Orthod 80: 890-895.

SAGHIRI MA, TANIDEH N, GARCIA-GODOY F, LOTFI M, KARAMIFAR K AND AMANAT D. 2012. Subcutaneous connective tissue reactions to various endodontic biomaterials: an animal study. J Dent Res Dent Clin Dent Prospects 7: 15-21.

SANTOS RL, MOURA MFL, CARVALHO FG, GUÊNES GM, ALVES PM AND PITHON MM. 2014a. Histological analysis of biocompatibility of ionomer cements with an acid-base reaction. Braz Oral Res 28: 1-7.

SANTOS RL, PITHON MM, FERNANDES AB, CABRAL MG AND RUELLAS AC. 2010. Biocompatibility of orthodontic adhesives in rat subcutaneous tissue. J Appl Oral Sci 18: 503-508.

SANTOS RL, PITHON MM, MARTINS FO, ROMANOS MT AND RUELLAS AC. 2012. Evaluation of cytotoxicity and degree of conversion of glass ionomer cements reinforced with resin. Eur J Orthod 34: 362-366.

SANTOS RL, SAMPAIO GA, DE CARVALHO FG, PITHON MM, GUÊNES GM AND ALVES PM. 2014b. Influence of degree of conversion on the biocompatibility of different composites in vivo. J Adhes Dent 16: 15-20.
SELIMOVIĆ-DRAGA ̌ M, HUSEINBEGOVIĆ A, KOBAŠLIJA S AND HATIBOVIĆ-KOFMAN S. 2012. A comparison of the in vitro cytotoxicity of conventional and resin modified glass ionomer cements. Bosn J Basic Med Sci 12: 273-278.

SHAPIRO H, LUTATY AAND ARIEL A. 2011. Macrophages, Meta-Inflammation, and Immuno-Metabolism. Scientific World J 11: 21-25.

SOUZA PP, ARANHA AM, HEBLING J, GIRO EM AND COSTA CA. 2006. In vitro cytotoxicity and in vivo biocompatibility of contemporary resin-modified glassionomer cements. Dent Mater 22: 838-844.

VIOLA NV, GUERREIRO-TANOMARU JM, DA SILVA GF, SASSO-CERRI E, TANOMARU-FILHO M AND CERRI PS. 2012. Biocompatibility of an experimental MTA sealer implanted in the rat subcutaneous: quantitative and immunohistochemical evaluation. J Biomed Mater Res B Appl Biomater 100: 1773-1781.

VOSOUGHHOSSEINI S, LOTFI M, MORADZADEH M, AGHBALI A, RAHIMI S, SAGHIRI M, ZAND V, MEHDIPOUR M, RANJKESH B AND DOOSTI S. 2012. Comparison of two histopathologic methods for evaluating subcutaneous reaction to mineral trioxide aggregate. Med Oral Patol Oral Cir Bucal 17: e41-44.

XIE D, ZHAO J, YANG Y, PARK J, CHU TM AND ZHANG JT. 2008. Preparation and evaluation of a high-strength biocompatible glass-ionomer cement for improved dental restoratives. Biomed Mater 3: 1-12.

YANG WK, KO HJ AND KIM MR. 2012. Evaluation of the rat tissue reaction to experimental new resin cement and mineral trioxide aggregate cement. Restor Dent Endod 37: 194-200.

ZHOU J, TSAI YT, WENG H, BAKER DW AND TANG L. 2011. Real time monitoring of biomaterial-mediated inflammatory responses via macrophage-targeting NIR nanoprobes. Biomater Sci 32: 9383-9390. 